\title{
Clinical Reasoning: A 6-week-old infant with migrating focal seizures
}

Ittai Bushlin, MD, PhD, Lacey Smith, MS, CGC, Jurriaan M. Peters, MD, and Christelle Moufawad El Achkar, MD

Neurology ${ }^{\circledR}$ 2020;94:178-183. doi:10.1212/WNL.0000000000008842
Correspondence

Dr. Bushlin

Ittai.Bushlin@

childrens.harvard.edu

\section{Section 1}

A 6-week-old previously healthy boy who had been born at term presented with episodes of right facial twitching lasting 30 seconds, occurring multiple times daily. Neurologic examination was normal. Maternal pregnancy and birth history was unremarkable. Family history was negative for seizures. Initial EEG monitoring showed multifocal spikes (figure, A and B) and multifocal seizures, some that were clinically associated with facial twitching. He was treated with phenobarbital.

\section{Questions for consideration:}

1. What are possible etiologies for multifocal seizures in an infant?

2. What testing should be done to evaluate for underlying etiology? 


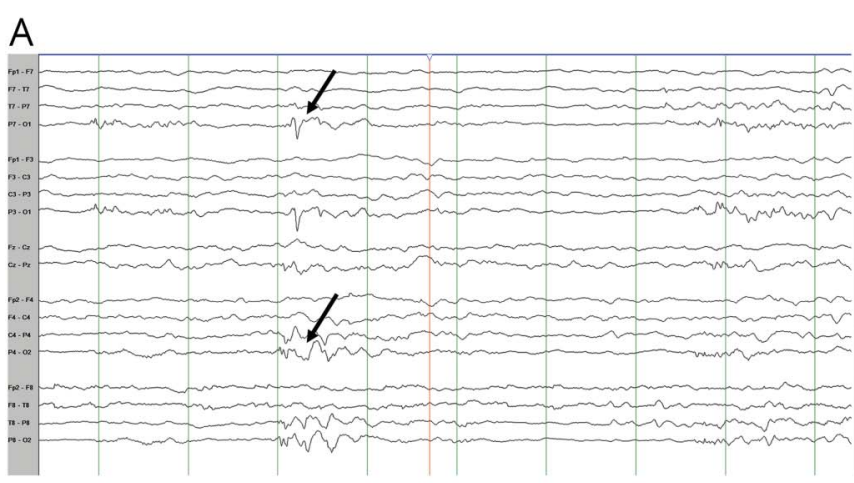

C

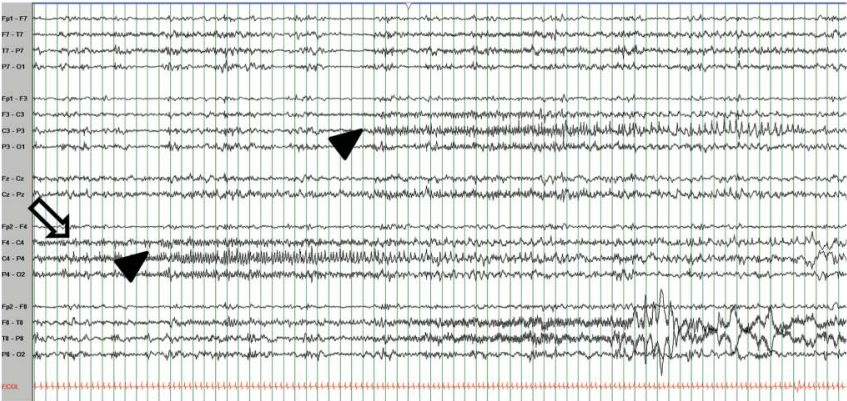

B

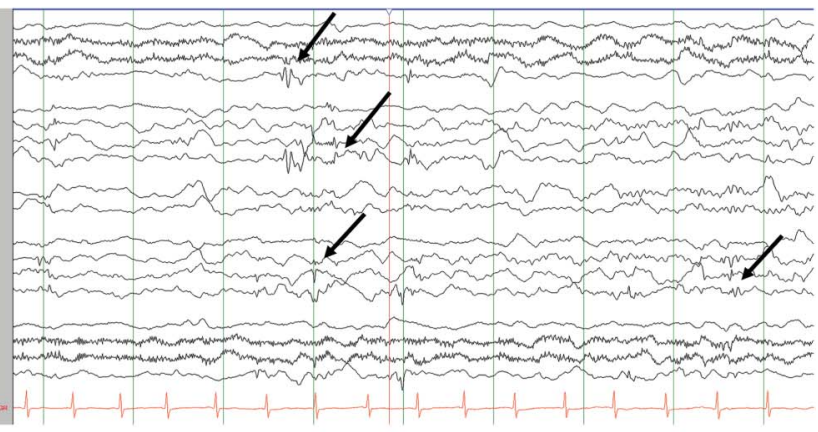

D

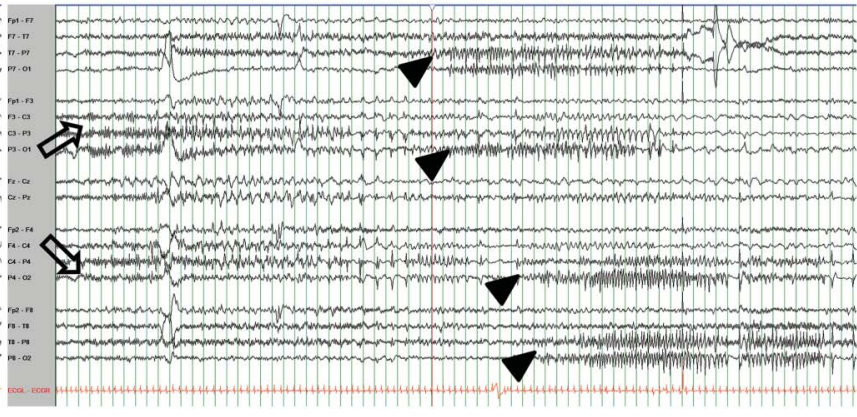

Interictal EEG examples showing bi-occipital spikes (A) and multifocal spikes (B) (arrows). LFF $1 \mathrm{~Hz}$, HFF $70 \mathrm{~Hz}$, sensitivity $10 \mu \mathrm{V} / \mathrm{mm}$, time base $15 \mathrm{~mm} / \mathrm{s}$. Each green line $=1$ second. (C) Focal seizure starting at C4/P4, migrating to C3/P3. Arrows show fast activity prior to seizure onset; arrowheads show points of seizure onset and migration. LFF $1 \mathrm{~Hz}$, HFF $70 \mathrm{~Hz}$, sensitivity $30 \mu \mathrm{V} / \mathrm{mm}$, time base $2 \mathrm{~mm} / \mathrm{s}$. Each green line $=1$ second. (D) Focal seizure starting at biparasagittal regions, migrating to P7, then P3, P4, and P8. Arrows show fast activity prior to seizure onset; arrowheads show points of seizure onset and migration. LFF $1 \mathrm{~Hz}$, HFF $70 \mathrm{~Hz}$, sensitivity $30 \mu \mathrm{V} / \mathrm{mm}$, time base $2 \mathrm{~mm} / \mathrm{s}$. Each green line $=1$ second.

GO TO SECTION 2 


\section{Section 2}

Possible etiologies for multifocal seizures in infants include (1) brain structural abnormalities such as traumatic brain injury, stroke, cortical malformation, or mass, (2) an acute infectious or inflammatory process causing meningitis or encephalitis, or (3) a metabolic or genetic process. Initial testing should include MRI brain and CSF analysis for possible infection. In this case, head ultrasound on the day of presentation showed no hemorrhage, MRI brain with spectroscopy the next day was normal, and CSF routine studies plus neurotransmitter analysis were normal without evidence of pleocytosis, making structural or infectious/inflammatory causes less likely. Screening metabolic and genetic testing were sent, including electrolytes, plasma amino acids, urine organic acids, acylcarnitine profile, chromosomal microarray, and an infantile epilepsy gene panel (GeneDx). While awaiting testing results, seizures became refractory to phenobarbital. Repeat EEG showed seizures that migrated across contiguous cortical regions (figure, $\mathrm{C}$ and D) - for example, starting in the bi-parasagittal region, spreading to the left temporal region and then to the right temporal region. Clinically, some seizures were associated with clonic movements of the arms and eye twitching lasting 1-2 minutes, sometimes with associated oxygen desaturation. Seizures were refractory to the addition of levetiracetam and a trial of IV pyridoxine.

\section{Questions for consideration:}

1. What syndrome is associated with migrating seizures?

2. What are possible associated genetic etiologies?

GO TO SECTION 3 


\section{Section 3}

Migrating focal seizures in this age group is associated with epilepsy of infancy with migrating focal seizures (EIMFS). EIMFS is an early-onset developmental and epileptic encephalopathy (DEE) in which seizures typically start within the first 6 months of life, are focal and asynchronous, and are often refractory to medications. Developmental plateau or regression occurs after onset of epilepsy. Heterozygous pathogenic variants in KCNT1, a sodium-activated potassium channel expressed in neurons and cardiomyocytes, are the most commonly identified genetic cause of EIMFS, although variants in other genes have been less commonly reported in cases of EIMFS, including SCN1A, SCN2A, SLC12A5, SLC25A22, TBC1D4, PLCB1, and CHD2. Variants in KCNT1 have also been associated with autosomal dominant nocturnal frontal lobe epilepsy; some patients with KCNT1-associated EIMFS have also been reported to have cardiac arrhythmias or pulmonary hemorrhage.
In the current case, metabolic testing and chromosomal microarray were normal. However, the infantile epilepsy gene panel demonstrated a heterozygous pathogenic variant in KCNT1 (c.1283G>A p.R428Q). This specific variant has been reported previously in 8 cases of EIMFS and 3 cases of nonspecific DEE, and has been demonstrated to have a strong gain of function effect on potassium channel opening. Although the exact mechanism of associated epileptogenesis is uncertain, it had been proposed that increased current through KCNT1 channels in excitatory neurons permits rapid neuronal repolarization, leading to increases in action potential firing rates. $^{1}$

\section{Question for consideration:}

1. Are there medications that are specific for treatment of this condition? 


\section{Section 4}

Four previous reports have described the use of quinidine, an antiarrhythmic agent and weak KCNT1 antagonist, in patients with EIMFS due to a KCNT1 R428Q variant. In one case, quinidine was titrated up to $42 \mathrm{mg} / \mathrm{kg} /$ day (serum level $1.5-4.0 \mu \mathrm{g} / \mathrm{mL}$ ) and resulted in improved seizure control in a patient who developed EIMFS at 10 weeks of life, but was not treated with quinidine until 25 months of age. ${ }^{2}$ In another case of a 9-month-old patient with EIMFS, quinidine was increased to $126 \mathrm{mg} / \mathrm{kg} /$ day and was associated with development of ventricular tachycardia, so the dose was reduced to $73 \mathrm{mg} / \mathrm{kg} /$ day and was associated with a moderate decrease in seizures. ${ }^{3}$ In one other case, quinidine was ineffective at improving seizure burden in a 1.5-month-old patient with EIMFS at a goal dose of $50 \mathrm{mg} /$ $\mathrm{kg} /$ day and a maximum serum quinidine level of $1.3 \mu \mathrm{g} / \mathrm{mL}{ }^{4}$

There are 9 additional reports describing use of quinidine in 16 patients with EIMFS due to KCNT1 variants other than R428Q. Five patients showed some improvement in seizure frequency with quinidine treatment ${ }^{5-8}$ while 11 did not, although in some of these cases quinidine use was limited by prolongation of the QT interval or development of arrhythmia. Notably, in the patients in whom quinidine has been effective in reducing seizures, there have not been significant developmental gains.

In the current case, a high frequency of seizures (17-120 per day) continued despite use of phenobarbital, levetiracetam, phenytoin, lacosamide, and topiramate at doses in the therapeutic range. Quinidine was added at 9.5 weeks of age and initially titrated up to $35 \mathrm{mg} / \mathrm{kg} /$ day over 2 days. One day after reaching $35 \mathrm{mg} / \mathrm{kg} / \mathrm{day}$ (and a serum quinidine level of $0.5 \mu \mathrm{g} /$ $\mathrm{mL}$ ), seizure frequency decreased from 106 per day to 1 per day. However, several days later, seizure frequency increased up to 91 per day, so quinidine was increased to $50 \mathrm{mg} / \mathrm{kg} / \mathrm{day}$, after which seizures decreased to 13 per day (at a quinidine level of $1.2 \mu \mathrm{g} / \mathrm{mL}$ ). However, this dose was associated with QT interval prolongation to $511 \mathrm{~ms}$, so quinidine dosing was reduced to $30 \mathrm{mg} / \mathrm{kg} /$ day and seizure frequency again increased to 80-130 per day. Vigabatrin and stiripentol were added, with only modest benefit. At 10 months of age, the patient continues to have frequent daily seizures, and continues to be significantly delayed with poor head control, intermittent eye tracking, and evolving spasticity.

\section{Discussion}

There are now 20 reported cases of use of quinidine for KCNT1-associated EIMFS, including this report, with 9 patients having at least a partial reduction in seizure frequency, and 11 patients having no reduction in seizures. The reason for response variation is unclear, but some factors that may influence treatment response include the type of variant, age at treatment onset, and pretreatment seizure frequency. In addition, there is some debate as to whether quinidine can cross the blood-brain barrier at doses that do not prolong the QT interval. In vitro modeling may help predict which KCNT1 variants may be more likely to respond to quinidine and may be useful for developing more potent KCNT1 antagonists. For the time being, adjunct treatments exist; in a recent survey, the most commonly prescribed therapies for patients with KCNT1-related EIMFS were levetiracetam, phenobarbital, and ketogenic diet, with ketogenic diet or vigabatrin being relatively more successful for seizure control. ${ }^{9}$

Genetic testing may identify an etiology in up to $40 \%$ of cases of DEE. ${ }^{10}$ Genetic testing should be considered in infants with medically refractory seizures if there is a pathognomonic structural change on MRI (e.g., findings suggesting tuberous sclerosis), if MRI and initial infectious and initial metabolic testing are negative, or if a specific genetic syndrome is suspected (such as EIMFS or Dravet syndrome). Early recognition of EIMFS on EEG is critical as prompt sequencing of associated genes may affect medical treatment-for example, for KCNT1 variants, treatment with quinidine may be helpful; for SCN1A variants, avoidance of phenytoin is important; and, for some SCN2A variants, high-dose phenytoin may be effective. Diagnostic genetic results can also help end the diagnostic odyssey, inform genetic counseling discussions regarding recurrence risk and preconception and prenatal testing, and spare the patient from future testing such as repeated MRI scans, lumbar punctures, and exploratory bloodwork. Although quinidine, the current precision treatment for EIMFS due to a KCNT1 variant, may not be effective for every patient, the identification of new pathogenic variants in this gene can support future clinical and basic research efforts to develop more targeted treatments.

\section{Disclosure}

The authors report no disclosures relevant to the manuscript. Go to Neurology.org/N for full disclosures.

\section{Study funding}

No targeted funding reported.

Appendix Authors

\begin{tabular}{llll}
\hline Name & Location & Role & Contribution \\
\hline $\begin{array}{l}\text { Ittai Bushlin, } \\
\text { MD, PhD }\end{array}$ & $\begin{array}{l}\text { Boston } \\
\text { Children's } \\
\text { Hospital, MA }\end{array}$ & Author & $\begin{array}{l}\text { Drafted the manuscript } \\
\text { for intellectual content }\end{array}$ \\
\hline $\begin{array}{l}\text { Lacey Smith, } \\
\text { MS, CGC }\end{array}$ & $\begin{array}{l}\text { Boston } \\
\text { Children's } \\
\text { Hospital, MA }\end{array}$ & Author & $\begin{array}{l}\text { Revised the manuscript } \\
\text { for intellectual content }\end{array}$ \\
$\begin{array}{l}\text { Jurriaan } \\
\text { Peters, MD }\end{array}$ & $\begin{array}{l}\text { Boston } \\
\text { Children's } \\
\text { Hospital, MA }\end{array}$ & Author & $\begin{array}{l}\text { Revised the manuscript } \\
\text { for intellectual content }\end{array}$ \\
\hline $\begin{array}{l}\text { Christelle M. } \\
\text { El Achkar, MD }\end{array}$ & $\begin{array}{l}\text { Boston } \\
\text { Children's } \\
\text { Hospital, MA }\end{array}$ & Author & $\begin{array}{l}\text { Revised the manuscript } \\
\text { for intellectual content }\end{array}$ \\
& &
\end{tabular}




\section{References}

1. Milligan CJ, Li M, Gazina EV, et al. KCNT1 gain of function in 2 epilepsy phenotypes is reversed by quinidine. Ann Neurol 2014;75:581-590.

2. Bearden D, Strong A, Ehnot J, DiGiovine M, Dlugos D, Goldberg EM. Targeted treatment of migrating partial seizures of infancy with quinidine. Ann Neurol 2014;76: 457-461.

3. Yoshitomi S, Takahashi Y, Yamaguchi T, et al. Quinidine therapy and therapeutic drug monitoring in four patients with KCNT1 mutations. Epileptic Disord 2019; 21:48-54.

4. Numis AL, Nair U, Datta AN, et al. Lack of response to quinidine in KCNT1-related neonatal epilepsy. Epilepsia 2018;59:1889-1898.

5. Mikati MA, Jiang YH, Carboni M, et al. Quinidine in the treatment of KCNT1positive epilepsies. Ann Neurol 2015;78:995-999.
6. Abdelnour E, Gallentine W, McDonald M, Sachdev M, Jiang YH, Mikati MA. Does age affect response to quinidine in patients with $K C N T 1$ mutations? Report of three new cases and review of the literature. Seizure 2018;55:1-3.

7. Dilena R, DiFrancesco JC, Soldovieri MV, et al. Early treatment with quinidine in 2 patients with epilepsy of infancy with migrating focal seizures (EIMFS) due to gain-offunction KCNT1 mutations: functional studies, clinical responses, and critical issues for personalized therapy. Neurotherapeutics 2018;15:1112-1126.

8. McTague A, Nair U, Malhotra S, et al. Clinical and molecular characterization of KCNT1-related severe early-onset epilepsy. Neurology 2018;90:e55-e66.

9. Fitzgerald MP, Fiannacca M, Smith DM, et al. Treatment responsiveness in KCNT1related epilepsy. Neurotherapeutics 2019;16:848-857.

10. Berg AT, Coryell J, Saneto RP, et al. Early-life epilepsies and the emerging role of genetic testing. JAMA Pediatr 2017;171:863-871.

\section{Apply for the 2020 Palatucci Advocacy Leadership Program}

The $18^{\text {th }}$ annual Palatucci Advocacy Leadership Forum will take place July 23-26, 2020, at the Hyatt Tamaya Resort in Albuquerque, NM. The Academy desires to help applicants who have a clear passion, strong leadership potential, and an idea on how to advocate on behalf of their patients, community, or profession. The Palatucci Advocacy Leadership Forum will teach you how to:

- Turn your needs and those of your patients into action plans

- Develop media communication skills, whether in front of the camera or through written editorials

- Build and maintain relationships with reporters

- Represent your patients and profession with state and federal representatives

If you see problems or opportunities in your institution, local community, or on a state/national level that you want to address, learn more and apply by the March 9 deadline at $A A N$.com/view/PALF.

\section{Visit the Neurology ${ }^{\circledR}$ Resident \& Fellow Website}

Click on Residents \& Fellows tab at Neurology.org.

Now offering:

- Neurology ${ }^{\circledR}$ Resident \& Fellow Editorial team information

- "Search by subcategory" option

- E-pearl of the Week

- RSS Feeds

- Direct links to Continuum ${ }^{\circledR}$, Career Planning, and AAN Resident \& Fellow pages

- Recently published Resident \& Fellow articles

- Podcast descriptions

- Blogs by Editors and Resident \& Fellow team members

f Find Neurology ${ }^{\circledR}$ Residents \& Fellows Section on Facebook: facebook.com/AANResidentsAndFellows

Follow Neurology ${ }^{\circledR}$ on Twitter: @GreenJournal \#NeurologyRF

(0) Find Neurology ${ }^{\circledR}$ Residents \& Fellows Section on Instagram: @aanbrain \#NeurologyRF 


\section{Neurology}

\section{Clinical Reasoning: A 6-week-old infant with migrating focal seizures}

Ittai Bushlin, Lacey Smith, Jurriaan M. Peters, et al.

Neurology 2020;94;178-183 Published Online before print January 13, 2020

DOI 10.1212/WNL.0000000000008842

This information is current as of January 13, 2020

\section{Updated Information \&} Services

\section{References}

Subspecialty Collections

\section{Permissions \& Licensing}

\section{Reprints}

including high resolution figures, can be found at: http://n.neurology.org/content/94/4/178.full

This article cites 10 articles, 1 of which you can access for free at: http://n.neurology.org/content/94/4/178.full\#ref-list-1

This article, along with others on similar topics, appears in the following collection(s):

\section{All Genetics}

http://n.neurology.org/cgi/collection/all_genetics

\section{All Pediatric}

http://n.neurology.org/cgi/collection/all_pediatric

Antiepileptic drugs

http://n.neurology.org/cgi/collection/antiepileptic_drugs

EEG; see Epilepsy/Seizures

http://n.neurology.org/cgi/collection/eeg_see_epilepsy-seizures

Neonatal seizures

http://n.neurology.org/cgi/collection/neonatal_seizures

Information about reproducing this article in parts (figures,tables) or in its entirety can be found online at:

http://www.neurology.org/about/about_the_journal\#permissions

Information about ordering reprints can be found online:

http://n.neurology.org/subscribers/advertise

Neurology ${ }^{\circledR}$ is the official journal of the American Academy of Neurology. Published continuously since 1951, it is now a weekly with 48 issues per year. Copyright @ 2020 American Academy of Neurology. All rights reserved. Print ISSN: 0028-3878. Online ISSN: 1526-632X.

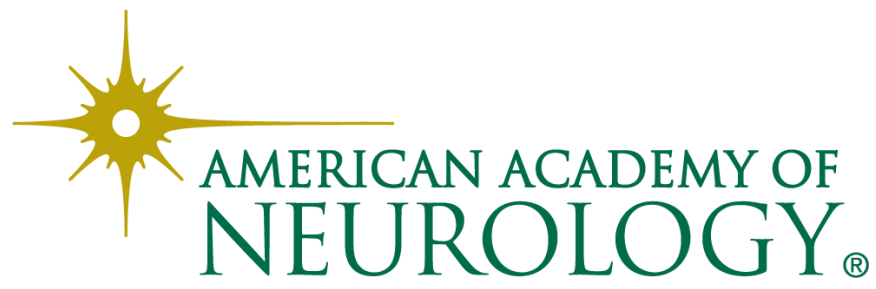

